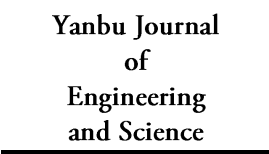

ISSN: 1658-5321
Vol. 3, October $2011(1432 \mathrm{H})$ www.yjes.org.sa

\title{
FAULT TOLERANT CONTROL OF INDUCTION MOTOR FED BY THREE PHASE INVERTER
}

\author{
E. E. El-kholy ${ }^{1}$, A. E. Kalas ${ }^{2}$, and M.Fawzi ${ }^{2}$ \\ 1 King Abdulaziz University, Faculty of Engineering, Rabigh, Elec. Eng. Dept., Saudi Arabia. \\ e_mail:eelkholy@yahoo.com \\ 2 Electrical Engineering Dept., Faculty of Engineering, Port-Said, Suez Canal University
}

\begin{abstract}
In this paper a new switching technique for Direct Torque Control (DTC) fault tolerant induction motor drive is presented, if one inverter leg is completely lost due to such abnormal condition, this system modifies the switching table of DTC system using the available stator voltage vectors in two phase mode with Four Switch Three Phase Inverter (FSTPI) topology to track the stator flux reference and directly control the torque and maintain the performance of induction motor as in the Six Switch Three Phase Inverter (SSTPI) mode. An experimental setup has been built in Laboratory using the interface circuit Advenchtech PCI 1711 to test the performance of the proposed method and the experimental results give a good agreement with the simulation results.
\end{abstract}

Keywords: Induction motor drive, Direct torque control, Fault tolerant control, Four switch three phase inverter.

\section{INTRODUCTION}

The reliability of adjustable speed drives is an area of great interest for all members of the drives community and market place. This particularly the case for the military, aerospace and automotive industries [1].

A commonly practiced method of improving reliability is to design the power circuit conservatively. A second method is to have parallel redundant operation of components or circuits. As an alternative to the redundancy technique, fault tolerant control has been presented in [2], [3].

The idea is to modify the drive control algorithm during a fault in such a way that the faulty drive continue to run in a degraded mode [4].

In [5],[6] a field oriented fault tolerant control has been introduced and in [7],[8] a PWM strategies under fault conditions are proposed.

More recently, DTC fault tolerant algorithms are presented and their performances are studied in [9],[10].

In this paper, a fault tolerant direct torque three phase induction motor drive systems is proposed.

The proposed system detects an open IGBT gate drive fault, disconnect the faulty phase and operate the system in four switch three phase inverter (FSTPI) topology, then the system selects the suitable stator voltage vector among the available four vectors which can be produced by four switch inverter topology to track the stator flux reference and directly control torque and flux and maintain the performance of induction motor as in the six switch three phase inverter (SSTPI). 


\section{DIRECT TORQUE CONTROL ALGORITHM AT NORMAL CONDITIONS}

A direct torque control of three phase induction motor drive system has been simulated in MATLAB-Simulink. The flux command $\varphi_{\mathrm{s}}^{*}$ and the torque command $\mathrm{T}_{\mathrm{e}}^{*}$ magnitudes are compared with the estimated values, and the errors are processed through hysteresis band controllers [11], as shown in Fig.1. The flux loop controllers have two levels of digital output according to the following relations:

$$
\begin{aligned}
& H=1 \text { for } E>+H B \\
& H=0 \text { for } E>-H B
\end{aligned}
$$

Where $2 \mathrm{HB} \psi=$ total hysteresis band width of the flux controller. The circular trajectory of the command flux vector $\bar{\varphi}_{\mathrm{s}}^{*}$ with the hysteresis band rotates in an anti-clockwise direction. The actual stator flux $\bar{\varphi}_{\mathrm{S}}$ is constrained within the hysteresis band and it tracks the command flux in a zigzag path. The torque control loop has three levels of digital output, which have the following relations:

$$
\begin{gathered}
\mathrm{H}_{\mathrm{Te}}=1 \text { for } \mathrm{E}_{\mathrm{T}}>+\mathrm{HB}_{\mathrm{T}} \\
\mathrm{H}_{\mathrm{Te}}=0 \text { for }-\mathrm{HB}_{\mathrm{T}}<\mathrm{E}_{\mathrm{T}}<+\mathrm{HB}_{\mathrm{T}} \\
\mathrm{H}_{\mathrm{Te}}=-1 \text { for } \mathrm{E}_{\mathrm{T}}<-\mathrm{HB}_{\mathrm{T}}
\end{gathered}
$$

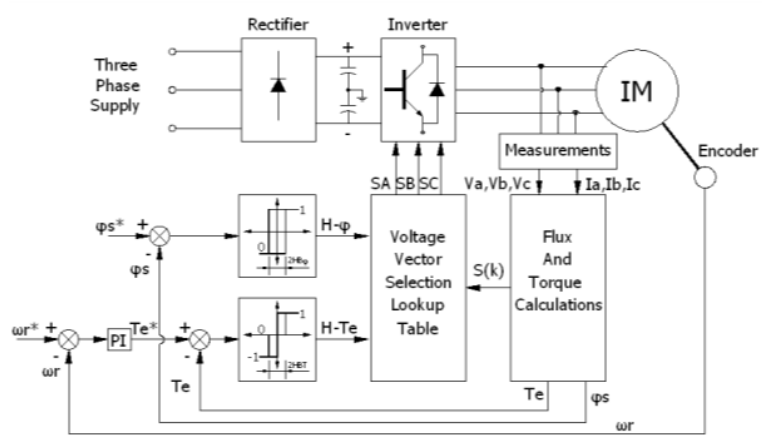

Fig.1. Direct Torque control block diagram

The feedback flux and torque are calculated from the machine terminals voltages and currents. The flux and torque calculations block also calculates the sector number $S(\mathrm{k})$ in which the flux vector $\bar{\varphi}_{\mathrm{s}}$ lies. There are six sectors (each $\pi / 3$ angle wide) as shown in Fig.2, the voltage vector selection lookup table block in Fig. 1 receives the input signals $\mathrm{H}_{\varphi}, \mathrm{H}_{\mathrm{Te}}$ and $\mathrm{S}(\mathrm{k})$ generates the appropriate control voltage vector (switching states) for the inverter by a lookup table, the inverter voltage vectors (six active and two zero states) and a typical stator flux vector trajectory are shown in Fig. 2 respectively.

Neglecting the stator resistance Rs of the machine, the stator voltage equation can be written as in (1)

$\bar{V}_{s}=\frac{d \bar{\varphi}_{s}}{d t}, \Delta \bar{\varphi}_{s}=\bar{V}_{s} \cdot \Delta$

Which means that $\bar{\varphi}_{\text {s }}$ can be changed incrementally by applying stator voltage vector $\bar{V}_{\mathrm{s}}$ for time increment $\Delta \mathrm{t}$. The flux increment vector corresponding to each of the six inverter voltage vector is shown in Fig.2.

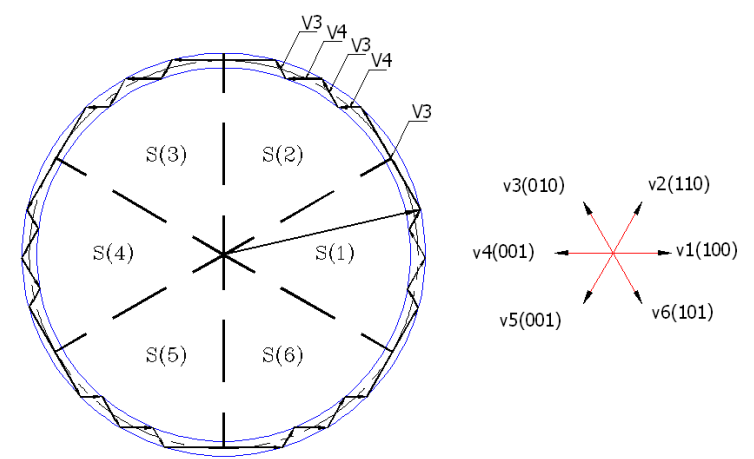

Fig.2. The Stator flux vector trajectory in DTC control

Note that the stator flux vector changes quickly by $\bar{V}_{\mathrm{S}}$, but $\bar{\varphi}_{\mathrm{r}}$ change is very sluggish due to large time constant of the rotor $\mathrm{Tr}$. Since $\bar{\varphi}_{\mathrm{r}}$ is more filtered, it moves uniformly at frequency $\omega_{\mathrm{e}}$, where as $\bar{\varphi}_{\mathrm{s}}$ movement is jerky. The jerky variation of stator flux and $\gamma$ angle introduces the torque ripple [12].

Table 1 summarizes the flux and torque changes for applying the voltage vectors if the flux vector $\bar{\phi}_{g}$ lies in sector (1), the flux can 
be increased by the vectors V2, V6 where as it can be decreased by the vectors V3, V5 .

Similarly, torque is increased by the vectors V2, V3, but decreased by the vectors V5, V6. The zero vectors (V0, V7) short circuits the machine terminals and keeps the flux and torque unaltered [13].

TABLE 1: THE DTC LOOKUP TABLE ACCORDING TO FLUX AND TORQUE CHANGES

\begin{tabular}{|c|c|c|c|c|c|c|c|}
\hline $\mathrm{H}_{\varpi}$ & $\mathrm{H}_{\mathrm{T} \boldsymbol{}}$ & $\mathbf{S}(\mathbf{1})$ & $\mathbf{S}(\mathbf{2})$ & $\mathbf{S}(\mathbf{3})$ & $\mathbf{S ( 4 )}$ & $\mathbf{S}(5)$ & $\mathbf{S}(\mathbf{6})$ \\
\hline \multirow{3}{*}{1} & 1 & $\mathrm{~V} 2$ & $\mathrm{~V} 3$ & $\mathrm{~V} 4$ & $\mathrm{~V} 5$ & $\mathrm{~V} 6$ & $\mathrm{~V} 1$ \\
\cline { 2 - 8 } & 0 & $\mathrm{~V} 0$ & $\mathrm{~V} 7$ & $\mathrm{~V} 0$ & $\mathrm{~V} 7$ & $\mathrm{~V} 0$ & $\mathrm{~V} 7$ \\
\cline { 2 - 8 } & -1 & $\mathrm{~V} 6$ & $\mathrm{~V} 1$ & $\mathrm{~V} 2$ & $\mathrm{~V} 3$ & $\mathrm{~V} 4$ & $\mathrm{~V} 5$ \\
\hline \multirow{3}{*}{0} & 1 & $\mathrm{~V} 3$ & $\mathrm{~V} 4$ & $\mathrm{~V} 5$ & $\mathrm{~V} 6$ & $\mathrm{~V} 1$ & $\mathrm{~V} 2$ \\
\cline { 2 - 8 } & 0 & $\mathrm{~V} 7$ & $\mathrm{~V} 0$ & $\mathrm{~V} 7$ & $\mathrm{~V} 0$ & $\mathrm{~V} 7$ & $\mathrm{~V} 0$ \\
\cline { 2 - 8 } & -1 & $\mathrm{~V} 5$ & $\mathrm{~V} 6$ & $\mathrm{~V} 1$ & $\mathrm{~V} 2$ & $\mathrm{~V} 3$ & $\mathrm{~V} 4$ \\
\hline
\end{tabular}

\section{FOUR SWITCH THREE PHASE INVERTER TOPOLOGY}

When an inverter phase leg is disconnected, the faulty phase terminal should be connected to the mid-point of the DC link in order to operate the machine in two phase mode, this topology of the inverter is called Four Switch Three Phase Inverter (FSTPI) and shown in Fig.3, a case study (disconnection of phase C) has been discussed and analyzed in the following section.

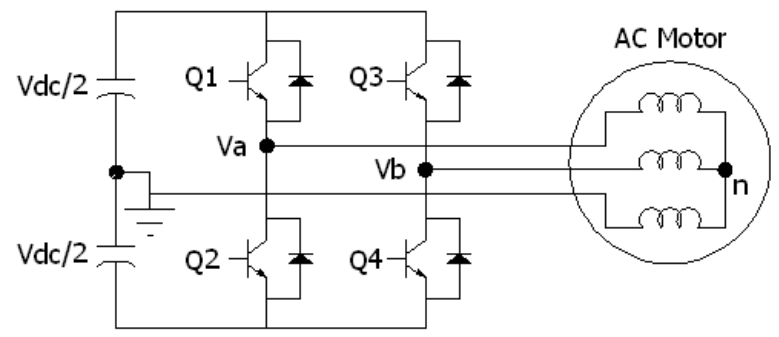

Fig.3. The four switch three phase inverter with phase (C) is connected to DC link mid-point

\section{FAULT TOLERANT CONTROL ALGORITHM}

If phase $\mathrm{C}$ is disconnected, the system will operate in (FSTPI) mode and Phase to common point voltages $\mathrm{V}_{\mathrm{a} 0}, \mathrm{~V}_{\mathrm{b} 0}, \mathrm{~V}_{\mathrm{c} 0}$ can be determined as a function of upper switches states as in (2).

$$
\left.\begin{array}{c}
V_{a 0}=\left(2 S_{1}-1\right) * \frac{V_{D C}}{2} \\
V_{b 0}=\left(2 S_{5}-1\right) * \frac{V_{D C}}{2} \\
V_{c 0}=0.0
\end{array}\right\}
$$

Where S1 and S3 are the switching states of the upper switches of phases $a$ and $b$ respectively. The combinations of switches $S 1, S 2, S 3, S 4$ result in four non zero general space vectors $\mathrm{V} 1, \mathrm{~V} 2, \mathrm{~V} 3, \mathrm{~V} 4$ as shown in Fig. 6 and there is no zero vectors as in case of (SSTPI) $[14,15,16,17]$.

The voltage vector $(\alpha-\beta)$ components can be calculated from stator phase voltages $\left(\mathrm{V}_{\mathrm{an}}, \mathrm{V}_{\mathrm{bn}}, \mathrm{V}_{\mathrm{cn}}\right)$ by using Clark's transformation as in (3).

$$
\left[\begin{array}{l}
V_{\alpha} \\
V_{\beta}
\end{array}\right]=\frac{2}{3}\left[\begin{array}{ccc}
1 & -\frac{1}{2} & -\frac{1}{2} \\
0 & \frac{\sqrt{3}}{2} & -\frac{\sqrt{3}}{2}
\end{array}\right]\left[\begin{array}{l}
V_{a n} \\
V_{b n} \\
V_{c n}
\end{array}\right]
$$

Table 2 shows the switching states and the corresponding voltage space vectors. In direct torque control the switching table select the suitable stator voltage vector from a suitable six nonzero vectors and two zero voltages, in FSTPI there are four nonzero vectors and no zero vectors as discussed earlier, these vectors divide the $(\alpha-\beta)$ plane into four sectors as shown in Fig.4. Table 3 shows the lookup table with the suitable voltages to control the flux and torque if phase $\mathrm{C}$ is disconnected.

TABLE 2: THE SWITCHING STATES AND THE CORRESPONDING VOLTAGE SPACE VECTORS.

\begin{tabular}{|c|c|c|}
\hline S1 & S3 & $\overline{\mathbf{V}}=\mathbf{V}_{\boldsymbol{\alpha}}+\mathbf{j} \mathbf{V}_{\boldsymbol{\beta}}$ \\
\hline 0 & 0 & $\overline{V_{1}}=\frac{V_{D C}}{3} \mathrm{e}^{-\frac{2 \pi}{3}}$ \\
\hline 1 & 0 & $\overline{V_{2}}=\frac{2 V_{D C}}{3} e^{-j \frac{\pi}{6}}$ \\
\hline 1 & 1 & $\overline{V_{3}}=\frac{2 V_{D C}}{3} \mathrm{e}^{\frac{\pi \pi}{3}}$ \\
\hline 0 & 1 & $\overline{V_{4}}=\frac{2 V_{D C}}{3} \mathrm{e}^{\frac{5 \pi}{6}}$ \\
\hline
\end{tabular}

TABLE 3: THE DTC LOOKUP TABLE

\begin{tabular}{|c|c|c|c|c|c|}
\hline $\boldsymbol{H}_{\boldsymbol{\varphi}}$ & $\boldsymbol{H}_{\boldsymbol{T e}}$ & $\mathbf{S}(\mathbf{1})$ & $\mathbf{S}(\mathbf{2})$ & $\mathbf{S ( 3 )}$ & $\mathbf{S}(\mathbf{4})$ \\
\hline \multirow{3}{*}{1} & 1 & $\mathrm{~V} 3$ & $\mathrm{~V} 4$ & $\mathrm{~V} 1$ & $\mathrm{~V} 2$ \\
\cline { 2 - 6 } & -1 & $\mathrm{~V} 2$ & $\mathrm{~V} 3$ & $\mathrm{~V} 4$ & $\mathrm{~V} 1$ \\
\hline \multirow{2}{*}{0} & 1 & $\mathrm{~V} 4$ & $\mathrm{~V} 1$ & $\mathrm{~V} 2$ & $\mathrm{~V} 3$ \\
\cline { 2 - 6 } & -1 & $\mathrm{~V} 1$ & $\mathrm{~V} 2$ & $\mathrm{~V} 3$ & $\mathrm{~V} 4$ \\
\hline
\end{tabular}




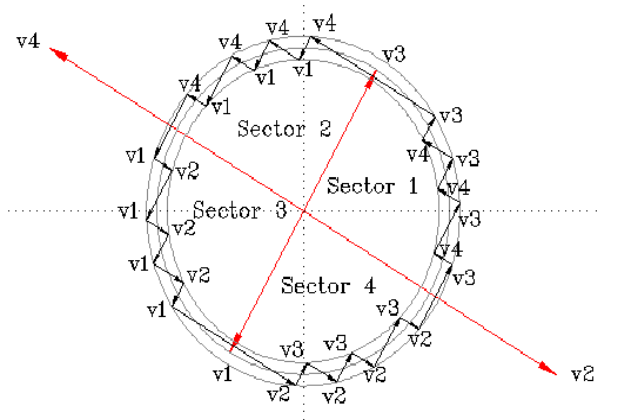

Fig.4 . The stator flux space vector trajectory if phase (C) is disconnected

\section{SIMULATION RESULTS}

The system has been simulated and analyzed in two cases, the first case is the normal operating conditions and the second case is when phase $\mathrm{C}$ is disconnected.

\subsection{NORMAL OPERATING CONDITIONS}

A direct torque control of three phase induction motor drive system has been simulated in MATLAB-Simulink. A load torque is a step function starting with 2 N.m and increased to $5 \mathrm{~N} . \mathrm{m}$ at $\mathrm{t}=0.6 \mathrm{sec}$ as shown in Fig. 5. The speed has been changed from 0 to $100 \mathrm{rad} / \mathrm{sec}$ with $100 \mathrm{rad} / \mathrm{sec}$ reference value according to the speed controller loop which includes a PI controller as shown in Fig. 6. And the stator current has been changed according to the load torque change as shown in Fig.7. The flux is controlled by using a hysteresis band controller, if the hysteresis band is set to very low value such as $\pm 0.01 \mathrm{~Wb}$, the stator flux magnitude and its vector locus will be as shown in Figs.8,9, and 10 .

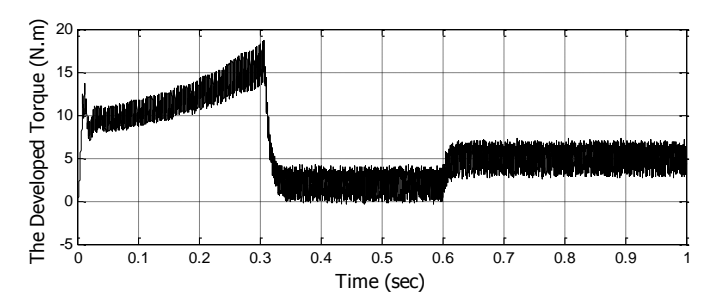

Fig.5. The developed torque

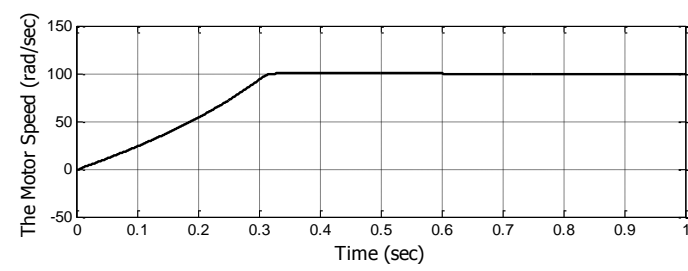

Fig.6. Motor speed

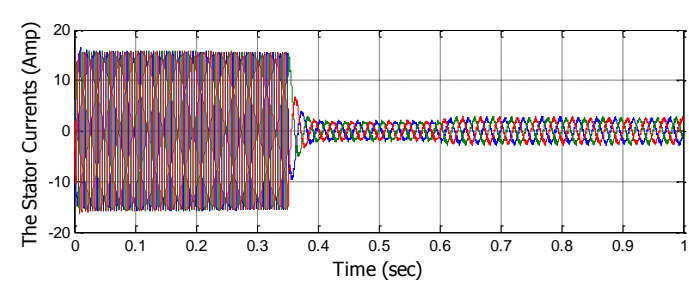

Fig.7. Stator currents

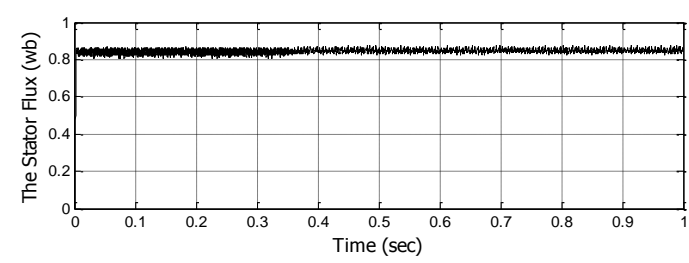

Fig.8. Stator flux amplitude

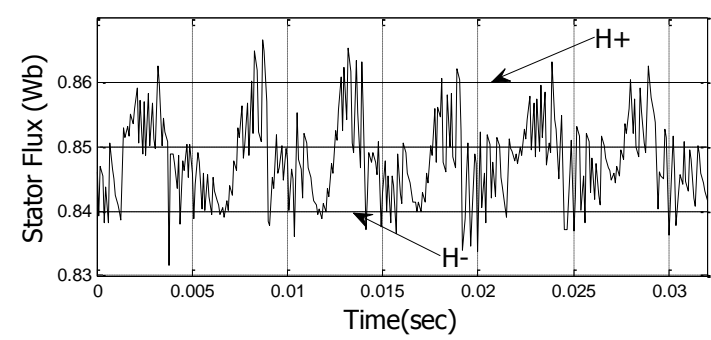

Fig.9. Zoom in the stator flux amplitude

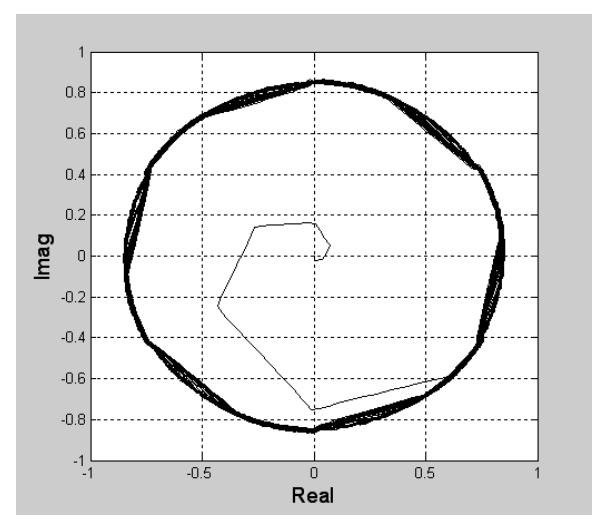

Fig.10. Stator flux space vector trajectory

\subsection{Phase (C) Is DisconNeCted}

If phase $\mathrm{C}$ is disconnected due to a such abnormal condition the stator voltage space vector will be as discussed earlier, there are only four vectors and the system selects the 
suitable stator voltage vector among the available four vectors to track the stator flux reference which has been decreased from 0.3 $\mathrm{Wb}$ to $0.2 \mathrm{~Wb}$, The simulation results in such case are shown in Figs. 11,12,13,14,and 15 .

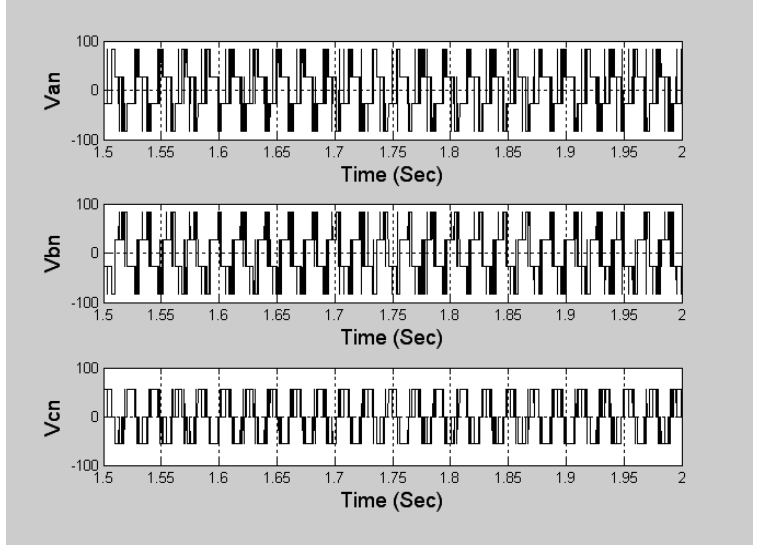

Fig.11. Phase voltages in FSTPI

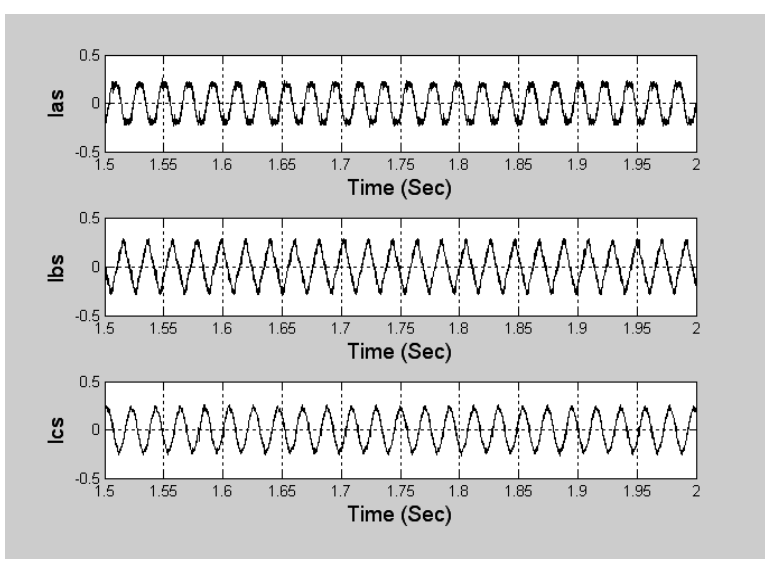

Fig. 12. Stator currents in FSTPI

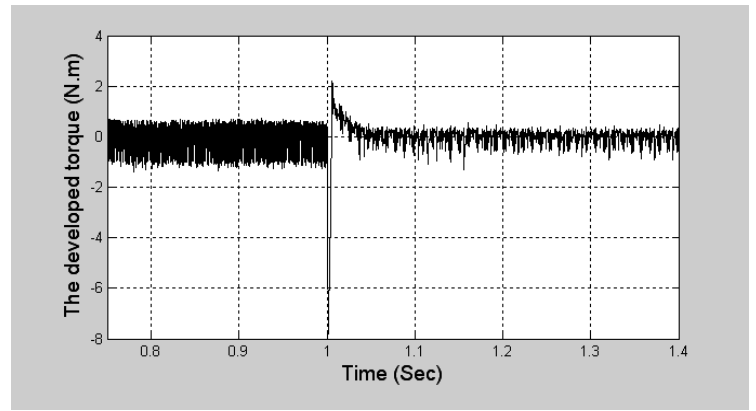

Fig. 13. The developed torque before and after phase disconnection

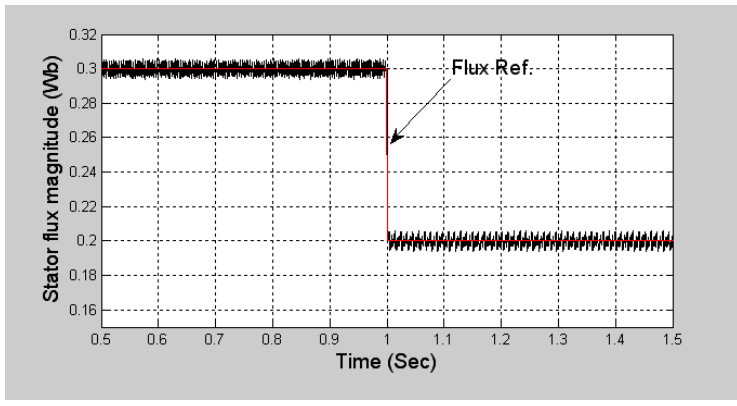

Fig. 14. Stator flux magnitude before and after phase disconnection

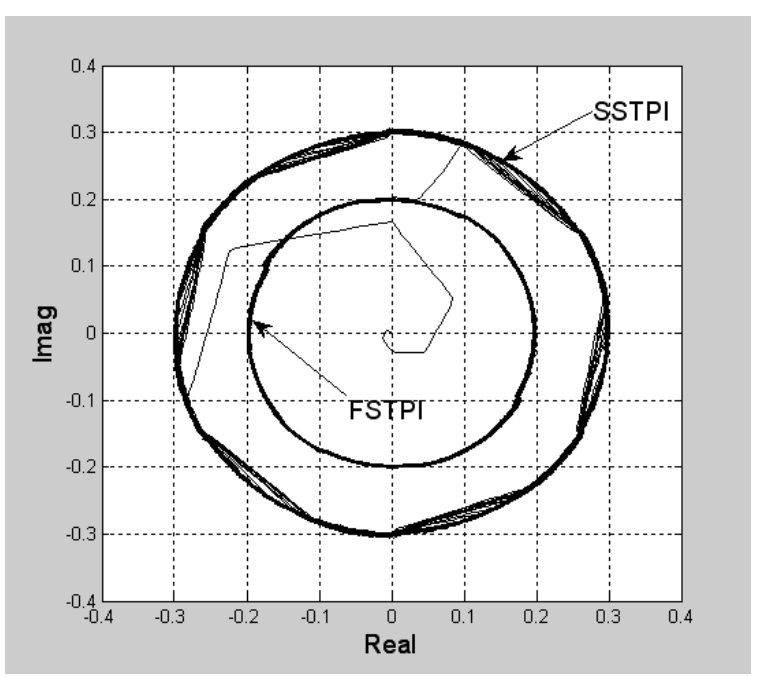

Fig. 15. Stator flux space vector trajectory before and after phase disconnection

\section{EXPERIMENTAL RESULTS}

The experimental setup has been built in laboratory using the interface circuit Advenchtech PCI1711 linked with MatlabSimulink Real Time Windows Target Toolbox to test the performance of the proposed method [18]. A three phase MOSFET (6*IRFP450) inverter has been used. The experimental results give a good agreement with the simulation results. The experimental test setup is shown in Fig.16, and its block diagram is shown in Fig. 17. 


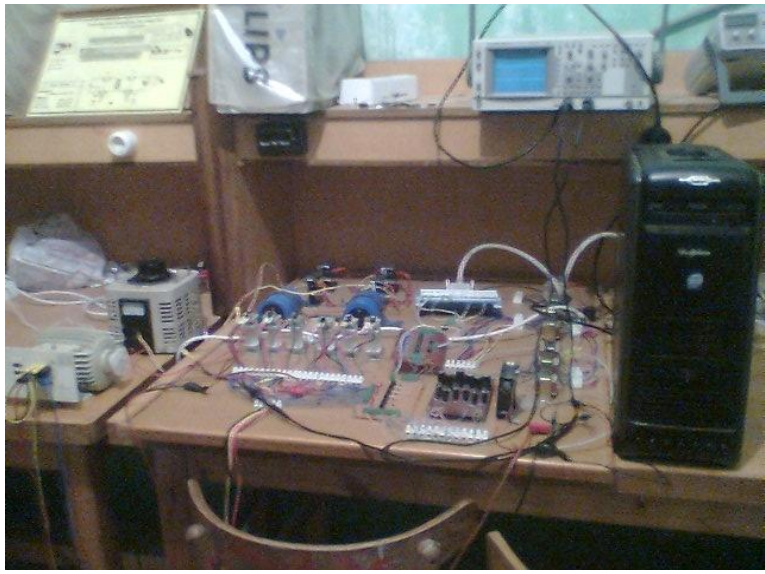

Fig. 16. Real view of the complete system

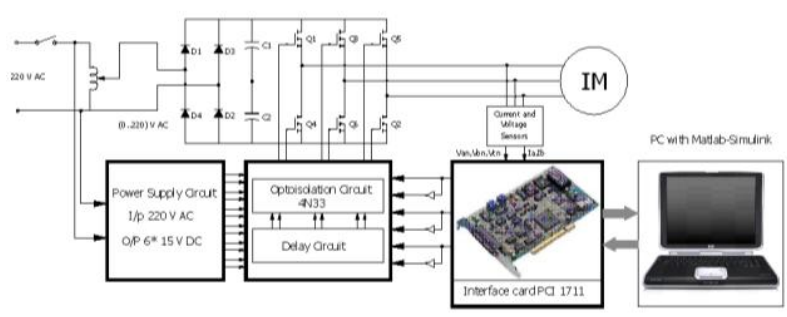

Fig. 17. Experimental setup block diagram

The transition from Six Switch Three Phase Inverter (SSTPI) topology to a Four Switch Three Phase Inverter (FSTPI) can be made experimentally by using a contactor or a relay to disconnect the faulty phase terminal and reconnect it to the mid-point of the DC link as shown in Fig.18, the phase voltages , currents and the developed torque in FSTPI are shown in Figs. 19,20,21 respectively.

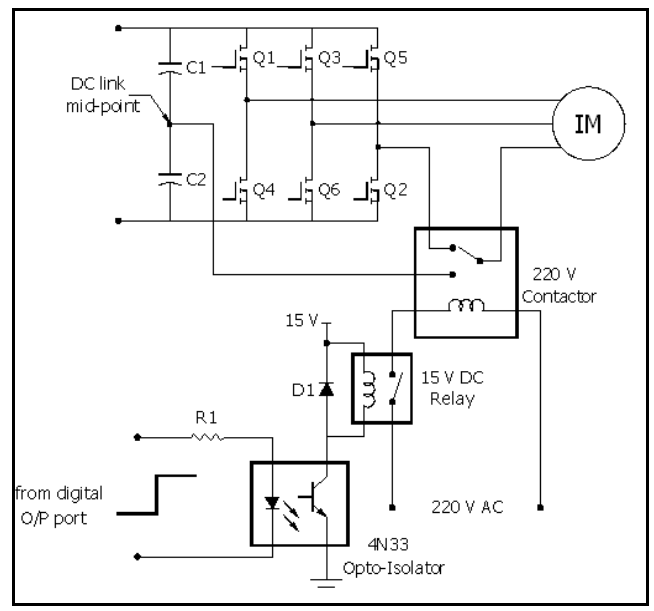

Fig. 18. Phase disconnection circuit

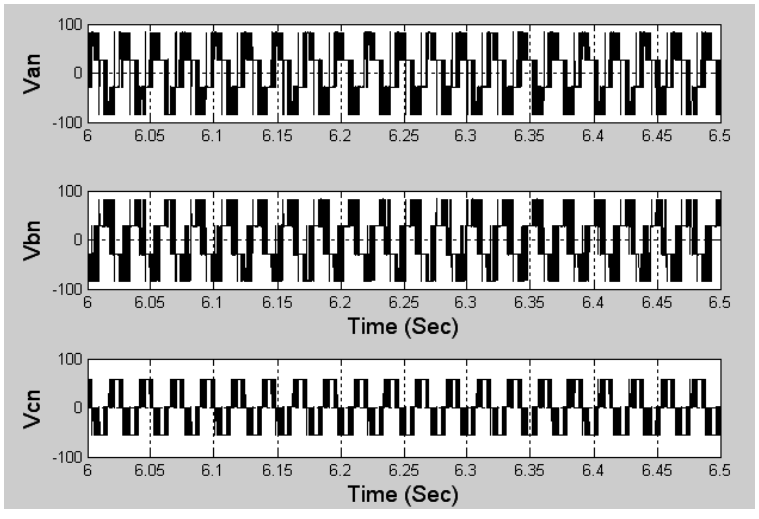

Fig. 19. Phase voltages in FSTPI

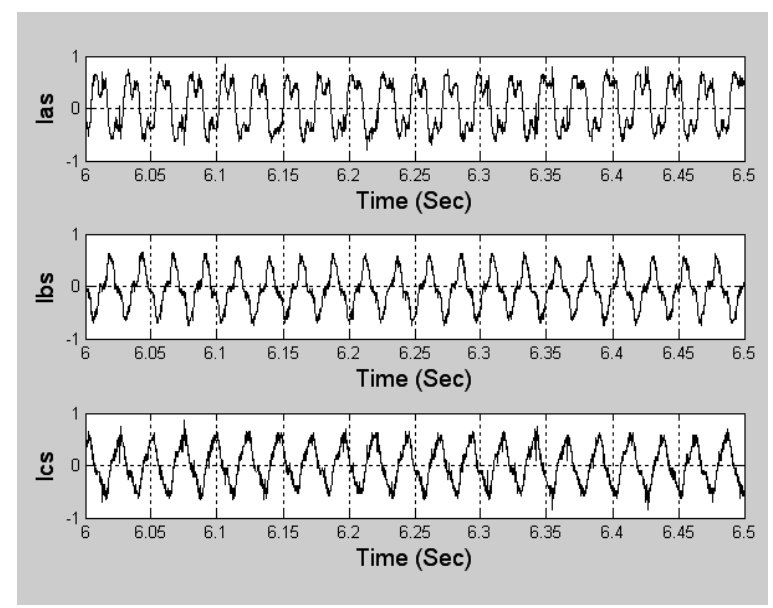

Fig. 20. Stator currents in FSTPI

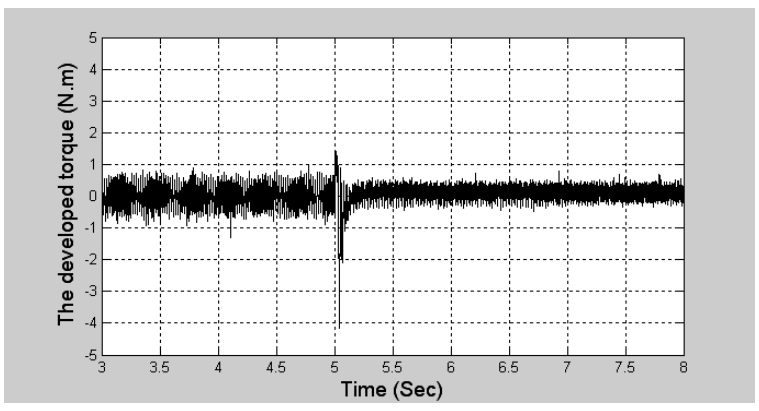

Fig. 21. The developed torque before and after phase disconnection

The reference flux has been decreased from $0.3 \mathrm{~Wb}$ to $0.2 \mathrm{~Wb}$, the stator flux magnitude will tracks the new reference value at the instant of applying the modified DTC FSTPI with a low amount of harmonics (varies from $0.17 \mathrm{~Wb}$ to $0.21 \mathrm{~Wb}$ ). Fig.22,23 show the stator flux magnitude and the stator flux space vector trajectory respectively. 


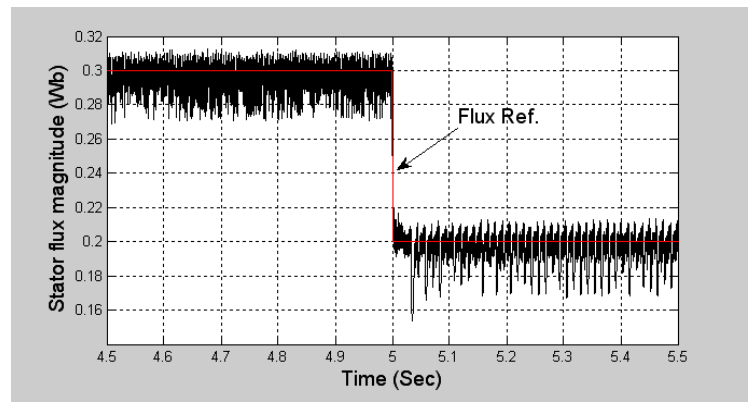

Fig. 22. Stator flux magnitude before and after phase disconnection

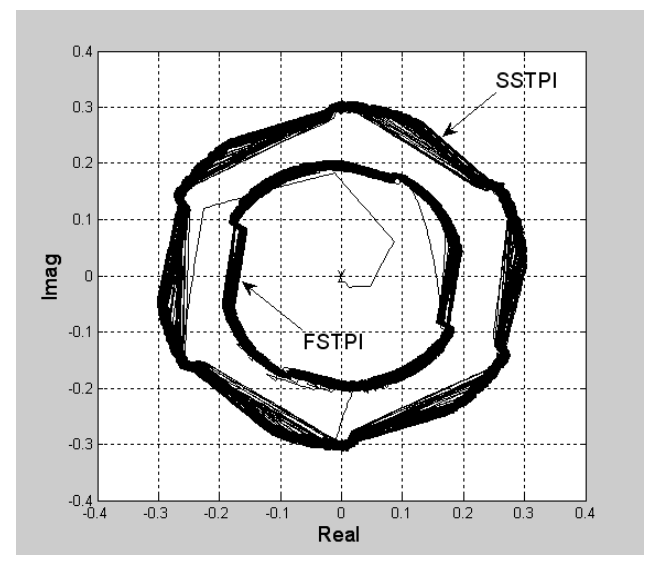

Fig. 23. Stator flux space vector trajectory before and after phase disconnection

\section{CONCLUSION}

A new switching technique for DTC fault tolerant induction motor drive is presented. This system firstly detects the fault, disconnect the faulty phase and operates the system in four switch three phase inverter (FSTPI) topology. The system has been simulated by MATLAB-Simulink and the results are obtained at normal and fault conditions. The proposed fault tolerant algorithm which depends on a modified switching table has been applied and the results show that the system can be operated by only two phases with nearly the same performance as of three phase mode. Also, an experimental setup has been built in Laboratory using the interface circuit Advenchtech PCI1711 to test the performance of the proposed method and the experimental results give a good agreement with the simulation results.

\section{APPENDIX}

The induction motor parameters are as follows:

$\begin{array}{ll}\text { Rated power : } & 1.1 \mathrm{Kw} \\ \text { Rated line voltage: } & 380 \text { Volts } \\ \text { No. of pole pairs: } & 2 \\ \text { Stator resistance: } & 7.4826 \mathrm{Ohm} \\ \text { Rotor resistance: } & 3.6840 \mathrm{Ohm} \\ \text { Mutual inductance: } & 0.4114 \mathrm{Henry} \\ \text { Stator leakage inductance: } & 0.0221 \mathrm{Henry} \\ \text { Rotor leakage inductance: } & 0.0221 \mathrm{Henry} \\ \text { Supply frequency: } & 50 \mathrm{~Hz} \\ \text { Motor speed: } & 1400 \mathrm{r} \cdot \mathrm{p} . \mathrm{m} . \\ \text { Moment of Inertia : } & 0.004 \mathrm{Kg} \cdot \mathrm{m}^{2} \\ \text { Rated load torque: } & 7.5 \mathrm{~N} . \mathrm{m} . \\ \text { DC Link Voltage : } & 110 \mathrm{Volt} \\ \text { Sample time : } & 1 \mathrm{e}^{-4} \mathrm{Sec} .\end{array}$

\section{REFERENCES}

[1] B.A. Welchko, T.A. Lipo, T.M. Jahns, S.E. Schulz, "Fault Tolerant Three Phase AC Motor Drive Topologies: A Comparison of Features, Cost, and Limitations", IEEE Trans. on Power Electronics, Vol.19(4), July 2004, pp.1108-1116.

[2] J.R. Fu, T.A. Lipo, " A Strategy to Isolate The Switching Device Fault of a Current Regulated Motor Drive", IEEE-IAS Conference, Vol.2, Oct. 2-8, 1993, pp. 1015-1020.

[3] M. B. R. Correa, C. B. Jacobina, E. R. C. Da Silva, A.M. N. Lima. "A General PWM Strategy for Four-Switch Three-Phase Inverters" IEEE Trans. on Power Electronics, Vol.21(6), Nov. 2006, pp.1618-1627.

[4] D. Kastha , B.K. Bose, "Investigation of Fault Modes of Voltage-Fed Inverter System For Induction Motor Drive". IEEE Trans. on Industry Applications, Vol.30(4), July/Aug. 1994, pp. 1028-1038.

[5] Benslimane TARAK, Chetate BOUKHMIS,"A New Diagnostic Method of Faulty Transistor in a Three-Phase Inverter", Istanbul Journal of Electrical \& Electronics Engineering IJEEE proceeding, Vol.6(2), 2006, pp.117-128.

[6] T.H. Liu, J.R. Fu, T.A. Lipo, "A Strategy for Improving Reliability of Field Oriented Controlled Induction Motor Drives", IEEE 
Trans. on Industry Applications, Vol.29(5), Sept.-Oct. 1993, pp. 910-918.

[7] J. Klima, "Time and Frequency Domain Analysis of Fault-Tolerant Space Vector PWM VSI-Fed Induction Motor Drive", IEE Proc.-Electr. Power Appl., Vol.152(4), July 2005, pp.765-774.

[8] J. Klima, "Analytical Investigation of an Induction Motor Drive Under Inverter Fault Mode Operations", 1EE Proc.-Electr. Power Appl., Vol.150(3), May 2003, pp. 255-262.

[9] Van Der Broeck, W. Heinz, Van Wyk, D. Jacobus, "A Comparative Investigation of a Three-Phase Induction Machine Drive with a Component Minimized Voltage-Fed Inverter under Different Control Options", IEEE Trans. on Industry Applications, Vol.20(2), March/April 1984, pp. 309-320.

[10] F. Blaabjerg, S. Freysson, H-H. Hansen, S. Hansen,"A New Optimized Space-Vector Modulation Strategy for a ComponentMinimized Voltage Source Inverter", IEEE Trans. on Power Electronics, Vol.12(4), Jul 1997, pp.704-714.

[11] I. Takahashi , T. Noguchi, "A New QuickResponse and High Efficiency Control Strategy of an Induction Machine", IEEE Trans. on Industry Applications, Vol.22(5), Sep/Oct 1986, pp. 820-827.

[12] B.K. Bose, Modern Power Electronics and AC Drives, Prentice Hall, 2001.

[13] Y.A. Chapuis, D. Roye, J.Davoine," Principles and Implementation of Direct Torque Control by Stator Flux Orientation of an Induction Motor ", Applied Power Electronics Conference and Exposition-APEC '95 Conference Proceedings., Vol.1, 1995, pp. 185-191.

[14] M. Azab, A.L. Orille, "Novel Flux and Torque Control of Induction Motor Drive Using Four Switch Three Phase Inverter", The 27 $7^{\text {th }}$ Annual Conference of the IEEE Industrial Electronics Society- IECON '01, Vol. 2, 2001, pp.12681273.

[15] A. Ben Abdelghani Bennani, M.G. Cherif, I.S. Belkhodja," New Fault Tolerant DTC Control for Induction Machine Drives", The $13^{\text {th }}$ Power Electronics and Motion Control Conference, EPE-PEMC 2008, 2008, pp 1149-1154.

[16] Phan Quoc Dzung, Le Minh Phuong, "A New Switching Technique for Direct Torque Control of Induction Motor using Four-Switch Three-
Phase Inverter", $7^{\text {th }}$ International Conference on Power Electronics and Drive Systems- PEDS 07, 2007, pp.1331-1336.

[17] D.T.W. Liang, Li. Jiang, "Flux Vector Modulation Strategy for a Four-Switch ThreePhase Inverter for Motor Drive Applications", 28th Annual IEEE Power Electronics Specialists Conference-1997. PESC 97, Vol.1(22), Jun 1997, pp. 612-617.

[18] Advantech PCI-1711/1731 PCI card user's Manual, Advantech Co., Ltd. $1^{\text {st }}$ Edition, 1999. 


\title{
التحكم في أعطال المحرك الحثي الأي يتم تغذيته بواسطة محول عكسي ثلاثي الأوجه
}

\author{
علوي الخولي1، أحمد كلس2 ، محمود فوزي2 \\ 1 قسم الهندسة الكهربائية - كلية الهندسة برابغ - جامعة الملك عبد العزيز - المملكة العربية السعودية

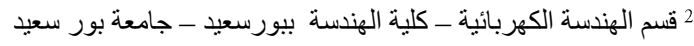

الملخص:

فى هذا البحث نم تقديم تقنية جديدة لتشغيل التحكم المباشر للعزم لمحرك حثى قادر على تحمل الأعطال. اذا تم فقدان أحد أفرع عاكس الجهد لأى ظروف غير طبيعية فإن هذه التقنية تقوم بتعديل جدول التوصيل الخاص بالتحكم المباشر فى العزم وذلك عن طريق استخدام متجهات الجهد المتاحة عبر وجهين من خلال أربعة مفاتيح فقط. و على ذلك فإن عاكس الجهد ثلاثى الأوجهه ذو الاربعة مفاتيح يقوم بتتبع القيمة المرجعية للفيض والتحكم المباثر فى عزم المحرك كما فى عاكس الجهـ ثلاثى الأوجهه ذو السته مفاتيح. تم عمل نظام معملى باستخدام كارتة معالجة البيانات Advenchtech PCI 1711 لاختبار أداء النموذج المقترح وقد وجد نوافق جيد بين النتائج العملية و النظرية. 